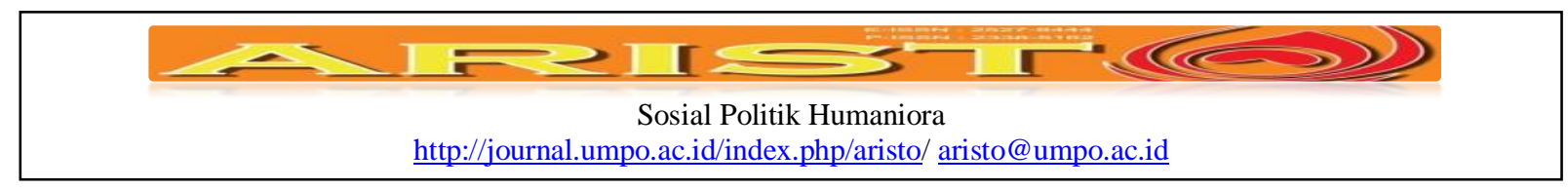

\title{
Perayaan Grebeg Suro sebagai Potensi Pengembangan Sektor Wisata Budaya Ponorogo
}

\author{
Khoirurrosyidin \\ Program Studi Ilmu Pemerintahan, Fakultas Ilmu Sosial dan Ilmu Politik, \\ Universitas Muhammadiyah Ponorogo \\ rosyidin.kh@gmail.com
}

\begin{abstract}
The celebration of "Grebeg Suro" is an annual agenda organized by the Ponorogo Regency Government and is always present the attention and long-awaited of Ponorogo people (domiciled in the city of Ponorogo as well as in other cities) as well as various communities from other cities, including tourists from overseas. Ponorogo regency government has responded well by compiling various agenda of activities that can coloring the celebration of "Grebeg Suro". Various events or competitions held in "Grebeg Suro", starting various events or lombase not the opening ceremony of "Grebeg Suro of Grebeg Suro, Reyog Festival National Center of Peace in "Aloon-Aloon Ponorogo", Kirap Pusaka, Closing of "Grebeg Suro", "Larung Risalah", and various other events, it was able to attract a large audience or visitors. The celebration of "Grebeg Suro" is actually derived from the customs of the community taken over by the Regional Government as the Annual Agenda by involving the community as a whole with a decision on the Head of Regent of Ponorogo Second Level Region No. 63 Juncto 130 Year 1987 about the Tourism Team of Ponorogo Level II Region.
\end{abstract}

Keyword: Celebration, Grebeg Suro, Tourism

\begin{abstract}
Abstrak
Perayaan "Grebeg Suro" merupakan sebuah agenda rutin tahunan yang diselenggarakan oleh Pemerintah Kabupaten Ponorogo dan selalu mendapatkan perhatian publik, serta dinantikan oleh masyarakat Ponorogo maupun kota lain yang ada di wilayah Jawa Timur ataupun Luar pulau Jawa, termasuk para turis dari mancanegara. Pemerintah Kabupaten Ponorogo telah merespon dengan baik dengan menyusun berbagai agenda kegiatan yang mampu mewarnai kemeriahan Perayaan "Grebeg Suro" tersebut. Berbagai acara dihelat dalam Perayaan "Grebeg Suro", mulai berbagai acara atau lomba sebelum acara Pembukaan "Grebeg Suro", Malam Pembukaan "Grebeg Suro", Festival Reyog Nasional, Pusat Keramaian di Alun Alun Ponorogo, Kirap Pusaka, Malam Penutupan "Grebeg Suro", "Larung Risallah", agenda tersebut telah menarik minat penonton atau pengunjung yang sangat besar. Perayaan "Grebeg Suro" sebenarnya berasal dari kebiasaan masyarakat yang kemudian dalam perkembanganya diambil alih oleh Pemerintah Daerah sebagai Agenda Tahunan yang melibatkan partisipasi masyarakat secara menyeluruh, yang di legal formalkan melalui Keputusan Bupati Kepala Daerah Tingkat II Ponorogo Nomor 63 juncto 130 Tahun 1987 tentang Tim Kepariwisataan Daerah Tingkat II Ponorogo.
\end{abstract}

Kata Kunci : Perayaan,Grebeg Suro, Pariwisata

\begin{tabular}{|ll} 
Submite & : 01 November 2017 \\
Review & : 01 Maret 2018 \\
Accepted & : 30 Juni 2018 \\
Surel Corespondensi & : yuli@usm.ac.id
\end{tabular}




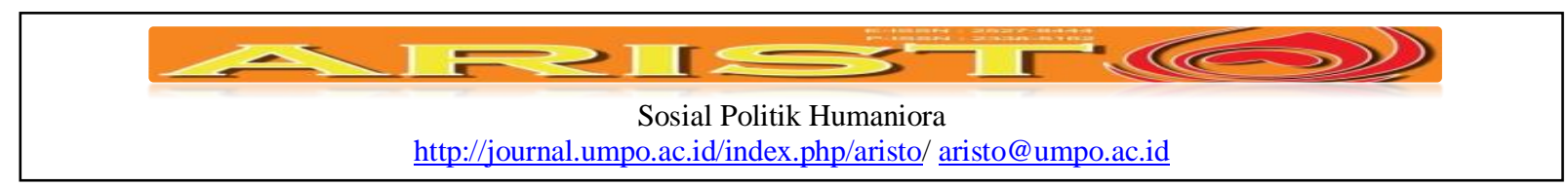

\section{Pendahuluan}

Pelaksanaan Perayaan Grebeg Suro merupakan momentum penting bagi masyarakat dalam maupun luar Ponorogo.Disamping sebagai barometer perkembangan seni budaya, Perayaan Grebeg Suro tersebut juga merupakan indikator kepedulian Pemerintah Kabupaten Ponorogo terhadap persoalan sosial ekonomi dan budaya masyarakat Ponorogo. Adapun alasan penyelenggaraan perayaan Grebeg Suro: 1), Memperbaiki mutu dari kesenian Reog Ponorogo sebagai aset kekayaan budaya Nasional, 2) menyokong kegiatan pariwisata daerah, di Kabupaten Ponorogo, 3). Merayakan tahun baru 1 Muharram, 4) meningkatkan perekonomian dari aktifitas tersebut.

Perayaan Grebek Suro sebenarnya berasal dari kebiasaan masyarakat yang diambil alih oleh Pemerintah Daerah sebagai Agenda Tahunan dengan melibatkan partisipasi masyarakat secara keseluruhan dengan dasar regulasi atau kebijakan yakni Keputusan Bupati Kepala Daerah Tingkat II Ponorogo Nomor 63 juncto 130 Tahun 1987 tentang Tim Kepariwisataan Daerah Tingkat II Ponorogo. Pariwisata menjadi sektor yang sangat diperhatikan secara khusus, karena sektor ini banyak menyumbang dalam perekonomian di daerah meupun secara nasional. Berangkat dari perhatian khusus di sektor pariwisata, pemerintah harus berupaya secara berkesinambungan untuk secara terus - menerus memberdayakan seluruh potensi dan sumber sumber penunjang kegiatan pariwisata, supaya dapat memberikan damapak terhadap peningkatan devisa Negara melalui wisata daerah.

Kabupaten Ponorogo merupakan salah satu kabupaten di Provinsi Jawa Timuryang memiliki potensi yang cukup tinggi di bidang kepariwisataan.Di Ponorogo terdapat wisata dimana didalamnya meliputi wisata alam, wisata religi dan wisata kebudayaan.Tercatat tidak kurang dari 26 objek wisata yang dapat diandalkan pengembangannya. "Bhumi Reyog" atau Kota Reog merupakan julukan dari Kabupaten Ponorogo karena kesenian Reog inilah berasal. Selain kesenian tersebut, sebenarnya Kabupaten Ponorogo memiliki banyak sekali Pondok Pesantren, yang terkenal diantaranya, Pondok Modern Darussalam Gontor yang terletak di desa Gontor, kecamatan Mlarak. Tidak hanya itu, di Kabupaten Ponorogo banyak sekali daya tarik wisata wisata alam seperti Telaga Ngebel, dan hamparan pegunungan dan bukit yang indah. Selama ini masyarakat masih hanya mengenal potensi wisata Ponorogo lewat Kesenian Reog, belum mengenal lebih jauh potensi alamnya. 


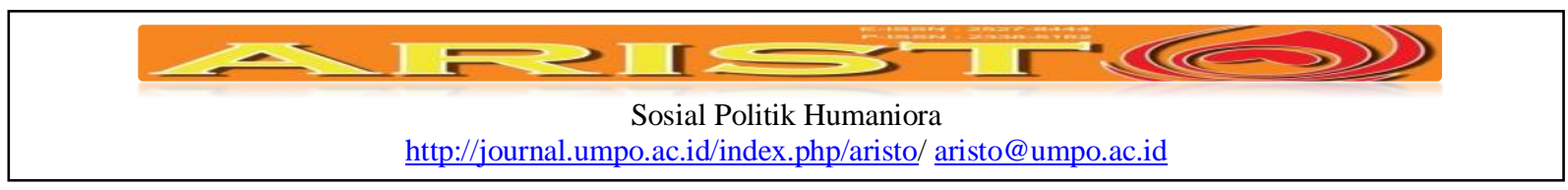

Kepala daerah beserta dengan staff dan jajarannya di kantor Pemerintahan Kabupaten Ponorogo melakukan pengambilan kebijakan, berdasarkan nilai - nilai luhur yang ada dan di percayai masyarakat, dimana wilayah ini dalam sejarah masa lalu memiliki local Widom berupa penyelenggaraan kegiatan (Grebeg Suro). Kegiatan "Grebeg Suro" merupakan kegiatan atau ritual yang dianggap sacral oleh masyarakat Ponorogo, yang diselenggarakan pada setiap tanggal 1 pada bulan Muharram (1 Suro pada tahun penanggalan Jawa), kegiatan tersebut secara umum bertujuan untuk melestarikan nilai - nilai luhur yang ada termasuk di dalam kesenian Reog Ponorogo.

Grebeg Suro secara kultural merupakan wujud syukur masyarakat terhadap sang pencipta, yang terbentuk melalui pesta rakyat. Kegiatannya sendiri berisi beberapa agenda, mulai dari: kesenian dan tradisi yang mempertunjukan kesenian reog dengan model festifal yang diikuti oleh berbagai daerah baik di pulau Jawa Atau di luar pulau Jawa bahkan dari Korea dan Hongkong, selain acara tersebut terdapat juga kegiatan Pawai Lintas Sejarah dan Kirab Pusaka, dan Larungan Risalah Do'a di Telaga Ngebel. Kegiatan ini sudah belasan tahun dilaksanakan.Tentunya ada nilai-nilai luhur yang terkandung didalamnya sehingga dipertahankan sampai sekarang oleh masyarakat Ponorogo.

Nilai - nilai luhur yang terkandung dalam kegiatan tersebut, bisa terlihat atau nampak pada berbagai gerakan, persimbolan dan juga sikap yang sedang dipertunjukan, nilai tersebut berbeda dnegan yang ada di daerah tersebut karena dalam pengemasan dan juga pertujukannya di tampilkan berbeda, atau secara sederhana karena kesenian ini berasal dari Ponorogo maka sudah jelas jika nilai - nilai dari tradisi ini hanya terdapat di wilayah tersebut.local wisdom merupakan nilai - nilai lokal yang dipercaya oleh masyarakat setempat dan diyakini kebenarannya.

"Grebeg Suro" yang ada di Kabupaten Ponorogo adalah merupakan pesta rakyat, disinilah terlihat antusias masyarakat yang secara berbeondong - bonding turut serta berpartisipasi dalam kegiatan tersebut, jika kita lihat secara lebih dekat, terlihat warga masyarakat Ponorogo sangat peduli dan mencintai kebudayaanya, khususnya dalam upaya pelestarian kebudayaan dan juga keseniannya. Dalam kegiatan ini terlihat budaya luhur yakni upaya gotong royong. Kegiatan ini diharapkan dapat memelihara nilai - nilai religi pada masyarakat Ponorogo, sehingga kesenian budaya di Kabupaten Ponorogo dapat terjaga.

Tinjauan sejarah memeperlihatkan jika masyarakat Ponorogo dahulu ketika menjelang malam 1 Suro, memiliki kebiasan melakukan tirakat semalam suntuk dan dibarengi dnegan 


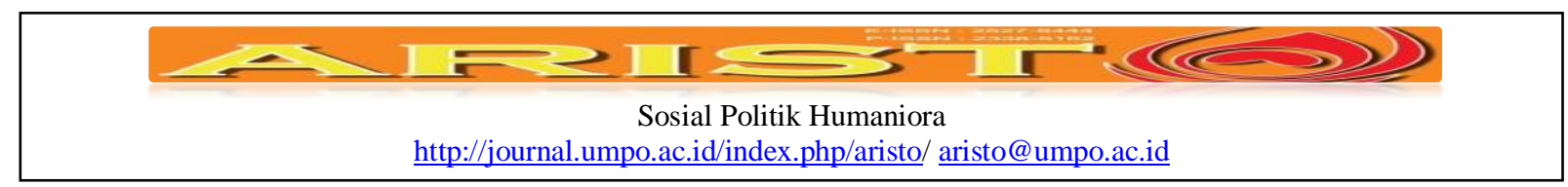

kegiatan berkeliling kota, dan berhenti di daerah Alun - alun, dalam perkembanganya kemudian, Pada era kepemimpinan Bupati Subarkah pada tahun 1987, kemudian memunculkan gagasan yang inovatif terkait pelestraian budaya, dal ini dilatarbelakang mulai menurunnya minat dan kepedulian pemuda dengan kesenian Khas Ponorogo, oleh sebab itu maka di gagas lah kegiatan, “Grebeg Suro” dan memadukannya dengan kegiatan Reog, awal penyelenggaraan kegiatan tersebut belum bersifat nasional, masih bersifat lokal.

Runutan agenda kegiatan "Grebeg Suro” dimulai dari penyelenggaraan Festival Reog Nasional, yang biasanya dilakukan selama 4 (empat) hari, yang melibatkan peserta yang berasal dari Kabupaten Ponorogo maupun luar Kabupaten. Selanjutnya peserta tersebut akan diambil 10 Besar group Reyog terbaik dan 10 besar pembina terbaik, kemudian sehari sebelum 1 Suro akan diselenggarakan Pawai Lintas Sejarah dan Kirab Pusaka dari kota lama ke kota tengah untuk mengenang perpindahan pusat pemerintahan Kabupaten Ponorogo dari kota lama ke kota tengah. Malam 1 Suro diadakan penutupan Festival Reog Nasional dan pengumuman lomba, dan tepat tanggal 1 Suro diadakan Larungan Risalah Do'a di Telaga Ngebel. Nilai Local Wisdom yang ada dalam aktifitas tersebut yakni nilai simbolik, nilai tanggung jawab, nilai keindahan, nilai moral, nilai hiburan, nilai budaya, nilai sosial, nilai ekonomi, nilai apresiasi, dan nilai religius.

“Grebeg Suro" sebagai sebuah potensi, perlu tersu untuk di kembangkan, dan juga harus di kolaboratif. Tahapan kegiatan yang bisa dilakukan yakni dengan membuat desain yang baik, akan tetapi harus terus dilakukan perbaikan, proses pengembangan tersebut harus bercorak kolaboratif, dnegan melibatkan berbagai pihak, perancanaan yang baik harus benar - benar menghasilkan kegiatan yang rapi, jelas dan meiliki pembangunan yang baik. (Rustiadi, 2009)

Perencanaan desain pengembangan merupakan sebuah aktifitas yang etrukur dan terencana dan tidak dapat terpisahkan, sehingga bisa secara progresif menyelesaikan maslah yang terjadi, Ada 4 (empat) kegiatan dalam proses deain dalam pengembangan yakni: a). memilih lingkungan yang akan digunakan, b). memilih format produk yang akan di pertunjukan dan pemanfaatan media untuk memperomosikan, c). menentukan format penilaian aktivitas atau kegiatan tersebut, d. mendesain dan mengembangan produk yang akan di pasarkan. Dalam pemilihan lingkungan dan format media yang akan di gunakan perlu diperhatikan beberapa hal, yakni: (1) perlengkapan/peralatan desain (tools of design), misalnya chart, video, komputer, dan lain -lain, (2) proses desain (process of design). Prosedur evaluasi lebih menekankan pada evaluasi formatif dengan pendekatan kualitatif. 


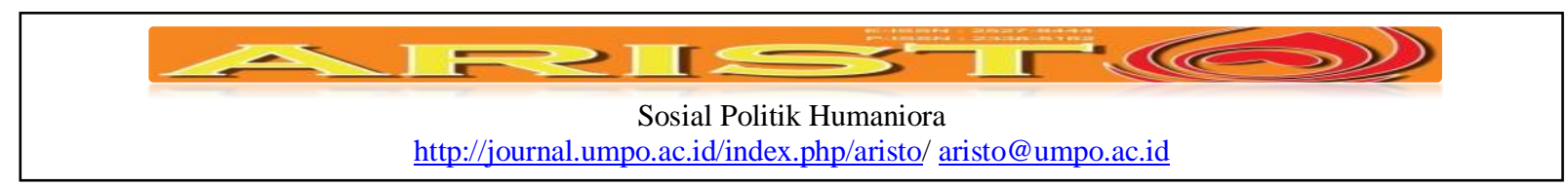

\section{Metode}

Penelitian ini berjenis kualitatif, dengan model deskriptif, jenis ini diambil karena peneliti akan berusaha mengungkap realitas sosial secara benar atau sesuai dengan kenyataan, di dasarkan pengumpulan kata - kata, yang akan di analisis secara relevan. Kemudian hasil analisis tersbeut kemudian di deskripsikan secara detail tanpa interpretasi ilmiah.

Dengan menggunakan teknik purposive sampling informan dalam penelitian ini yaitu :Kepala Bidang Pengembangan Pariwisata Dinas Kebudayaan, Pariwisata, Pemuda dan Olahraga Kabupaten Ponorogo, Kepala Seksi Obyek dan Daya Tarik Wisata Dinas Kebudayaan, Pariwisata, Pemuda dan Olahraga Kabupaten Ponorogo, Ketua Perayaaan Grebeg Suro Kabupaten Ponorogo Tahun 2015, (empat) orang masyarakat penjual dagangan sekitar kawasan wisata,2 (empat ) orang Wisatawan Domestik

Peneliti melakukan penguraian data, dengan teknik analisis kualitatif, sehingga memperoleh ilustrasi terkait fenomena atau pristiwa yang ada dan terjadi di lapangan, perolehan pristiwa tersebut diawali dengan pengumpulan data - data primer seperti hasil wawancara dari para informan, berdasarkan indikator yang sudah di tentukan.

\section{Hasil dan Pembahasan}

Dari berbagai pendapat informan, mereka mayoritas berpendapat bahwa Perayaan Grebeg Suro yang ada di Ponororgo sebenarnya adalah merupakan perayaan hari besar bagi umat Islam yang jatuh pada tgl 1 Muharram, dan diperingati sesuai dengan tradisi masyarakat yang disebut sebagai Tirakatan artinya kita sebagai masyarakat harus selalu mendekatkan diri dan juga memanjatkan doa serta Puji Syukur, kepada Tuhan Yang Kuasa agar senantiasa diberi keselamatan dan kesejahteraan baik di dunia maupun di akhirat. Hal ini dikuatkan oleh pendapat bapak

Ir. Mahmud Budihartono, M.Si menyatakan "Grebeg di Ponorogo mempunyai makna yaitu untuk mendekatkan diri dan memanjatkan doa kepada Yang Kuasa agar senantiasa diberi keselamatan dan kesejahteraan serta merupakan acara tahunan yang dirayakan setiap tanggal 1 Muharram (1 Suro pada tahun Jawa) dan kegiatan rutin bertujuan melestarikan nilai-nilai luhur budaya bangsa, yakni kekhasan dan keaslian Reog yang menjadi seni asli Ponorogo. 


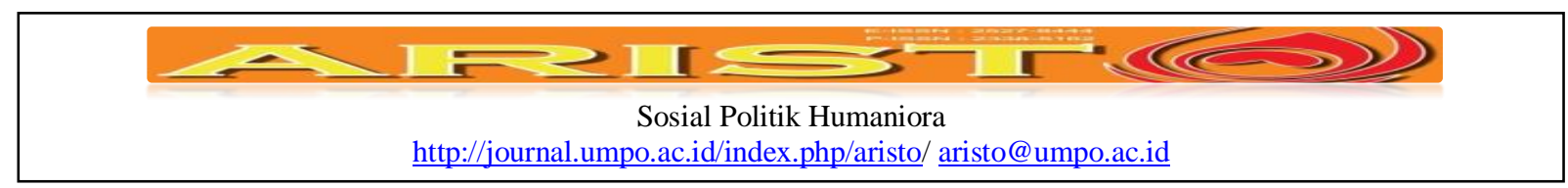

Sedangkan menurut Kepala dinas pariwisata Drh. Sapto Djatmiko, MM menjelaskan bahwa "Awalnya kegiatan Grebeg Suro Ponorogo ini, adalah acara atau kegiatan yang diadakan atau diselenggarakan dengan tujuan untuk memperingati datangnya tahun baru Islam (dalam istilah Jawa disebut Suro). Berbagai macam tata cara serta ritual dalam kegiatan ini diarahkan untuk menyambut bulan Sura bagi masyarakat Ponorogo adalah, bagian dari kegiatan religius atau keagamaan. Semua itu dilakukan hanya dalam proses pendekatan kepada Tuhan Yang Kuasa”.

Penjelasan diatas tentang kegiatan masyarakat Ponorogo di malam sebelum 1 Suro dnegan melakukan tirakat, dengan mengelilingi kota dan tidak tidur atau bergadang (melek'an), yang kemudian istilah tersebut Masyarakat Ponorogo melakukan melakukan tirakatan di bulan suro identik dengan sakralitas.mengelilingi kota dan tidak tidur pada malam satu suro (melekan) yang selanjutnya tradisi tersebut disebut Grebeg Suro. Cikal bakal Grebeg Suro diyakini ratusan tahun yang lalu telah dilakukan masyarakat Ponorogo secara spontan, responsif dalam menyambut tahun baru Suro “

Perayaan Grebek Suro sebenarnya berasal dari kebiasaan masyarakat yang diambil alih oleh Pemerintah Daerah sebagai Agenda Tahunan dengan melibatkan partisipasi masyarakat secara keseluruhan dengan didasarkan pada Keputusan Bupati Kepala Daerah Tingkat II Ponorogo Nomor 63 juncto 130 Tahun 1987 tentang Tim Kepariwisataan Daerah Tingkat II Ponorogo. Adapun untuk memperingati dilaksanakan Perayaan Grebeg Suro dalam wujud pesta rakyat Ponorogo, berbagai kegiatan digelar antara lain :Festifal Reyog,Pacuan Kuda,Simaan Al Qur'an, Pemilihan Kakang Senduk,Istiqozah, berbagai Pameran (Industri kecil, Bonsai, Adenium, Lukisan, Tanaman Hias Pasar Malam di Aloon-Aloon, Festival Reyog Nasional, Pawai Sepeda Unto, Kirab Pusaka,Ketoprak, Wayang Kulit, Musik Dangdut, Larung Risallah Doa, dan Festival Musik".

Agenda "Grebeg Suro" telah banyak "menyedot" perhatian serta rasa antusias masyarakat baik di wilayah Ponorogo atau dilur wilayah, pengunjung yang datang dapat memberikan efek ganda terhadap berbagai sektor lainnya, seperti meningkatnya perputarang uang, selama agenda tersebut yang membawa pemasukan bagi masyarakat di wilayah Ponorogo. 


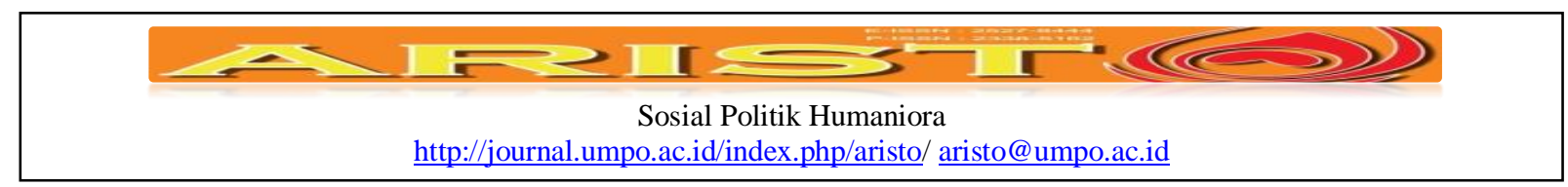

\section{Grebeg Suro dan Potensi Pengembangan Wisata budaya di Ponorogo}

Momentum grebeg suro bisa dijadikan kesempatan untuk meningkatkan potensi obyek wisata yang lain dikabupaten Ponorogo, hal ini sangat mungkinkarena Ponorogo memiliki beragam objek wisata, diantaranya Makam Batoro Katong yang menjadi bukti sejarah masuknya agama islam di kota Ponorogo, kemudian masih dalam rangkaina grebeg suro adalah kegiatan tradisional yang ada di masyarakat seperti Larung Risalah Do'a, Taman Rekreasi Singo Pitu, Pentas Wayang Kulit dan Reog Bulan Purnama dan Iain-Iain., yang semuanya dapat di kemas dalam satu paket wisata budaya, dan ditetapkan dalam kalender wisata Ponorogo.

Pemerintah kabupaten Ponorogo dalam mengembangkan potensi wisata budaya terlihat peduli dan serius, ini semua dilakukan agar peninggalan - peninggalan bersejarah, bisa kembali di pentaskan dalam kegiatan - kegiatan masyarakat, sehingga dapat dikenal dan tetap tumbuh subur, dalam pertujukan tersebut pesan - pesan sosial harus digalakan tentang menjaga warisan leluhur. Hal tersebut ternyata cukup berhasil, hal tersebut dapat dilihat dari perkembangan wisata di Kabupaten Ponorogo melalui jumlah kunjungan wisatawan, sejak tahun 2009 sampai dengan 2016 terus mengalami peningkatan. Farida menyampaikan selama 2015 tempat wisata paling banyak dikunjungi yaitu Telaga Ngebel dengan jumlah wisatawan 76.464 orang. Selanjutnya, tempat wisata paling banyak dikunjungi yaitu Masjid Tegalsari dengan jumlah wisatawan 62.725 orang. Sedangkan tempat wisata paling sedikit dikunjungi wisatawan yaitu Air Terjun Pletuk dengan jumlah wisatawan 1.170 orang.Wisatawan yang datang ke Ponorogo selama 2016 mencapai 249.294 orang.Rinciannya, wisatawan lokal sebanyak 249.229 orang dan wisatawan mancanegara sebanyak 65 orang.

Saat ini sarana dan prasrana penunjang mulai tersedia, guna melancarkan kegiatan wisata menuju kewilayah tersebut, berbagai model transportasi online juga telah banyak di Kabupaten Ponorogo, sehingga wisatawan tidak lagi mengalami kesusahan dalam menjangkau akses wilayah tersebut. Pengelolaan potensi wisata dilakukan dnegan mempersiapkan dna menggandeng, pihak swasta seperti: pengusaha penginapan, pengusaha rumah makan/restoran, pengusaha travel dan perbankan, hotel, restoran, dan biro perjalanan wisata, sehingga fasilitas tersebut secara perlahan terpenuhi, dan dapat membantu aksesbilitas wisatawan yang akan berkunjung ke destinasi yang ada di wilayah Ponorogo, menjadi lebih aman, nyaman dan mudah. 


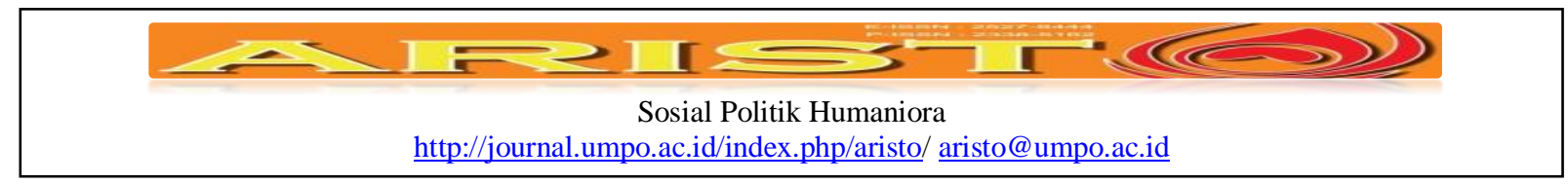

Gambar 1 Skema Potensi Pariwisata di Kabupaten Ponorogo

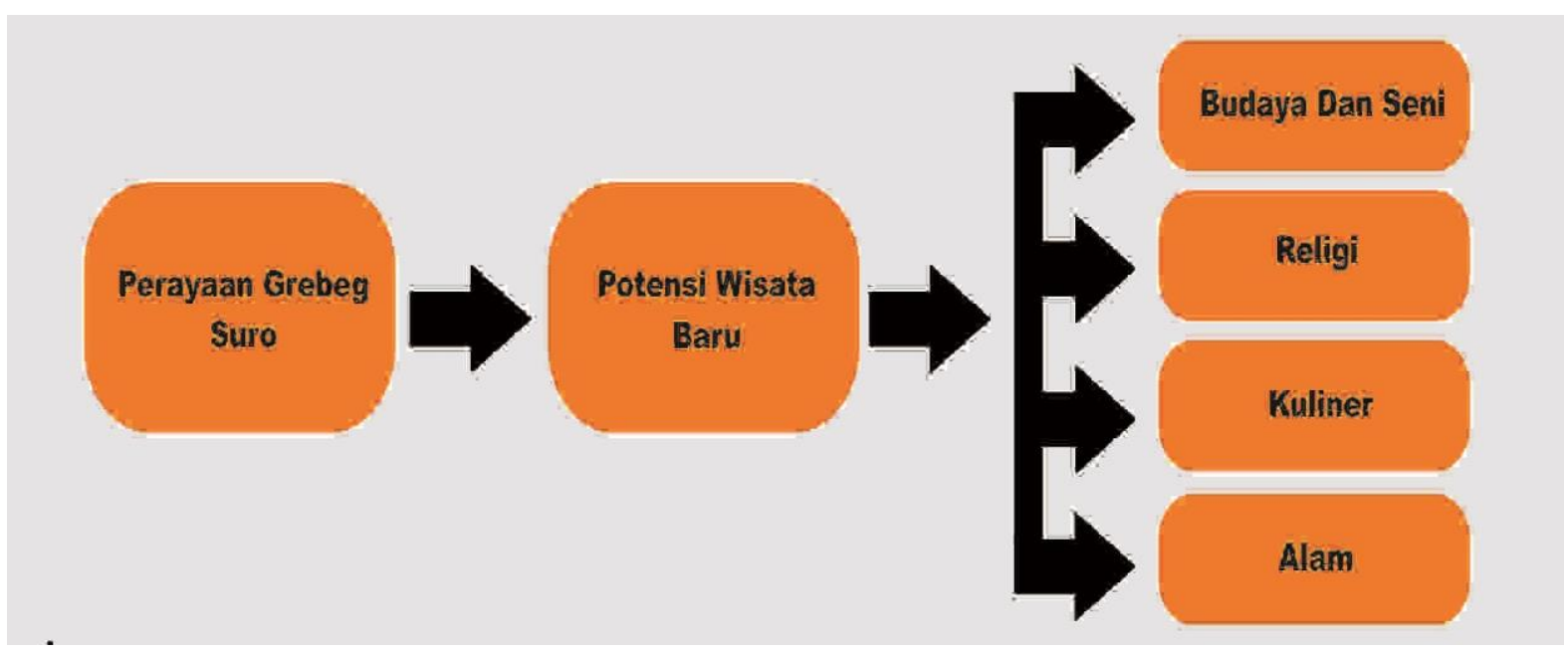

\section{Kesimpulan}

Agenda Wisata "Grebeg Suro" jika dilihat secara historis merupakan tradisi cultural masyarakat, sebagai wujud atau bentuk pesta rakyat di wilayah kabupaten Ponorogo. Acarnay terdiri dari kegiatan seni dan budaya, dimulai dari Festival Reog Nasional, Pawai Lintas Sejarah dan Kirab Pusaka, dan Larungan Risalah Do'a di Telaga Ngebel. Kegiatan ini telah lama dan memiliki nilai - nilai luhur masyarkaat yang di percaya.

Perayaan Grebek Suro sebenarnya berasal dari kebiasaan masyarakat yang diambil alih oleh Pemerintah Daerah sebagai Agenda Tahunan dengan melibatkan partisipasi masyarakat secara keseluruhan dengan didasarkan pada Keputusan Bupati Kepala Daerah Tingkat II Ponorogo Nomor 63 Juncto 130 Tahun 1987 tentang Tim Kepariwisataan Daerah Tingkat II Ponorogo.

Perayaan Grebeg Suro telah mampu membangkitkan berkembangnya obyek wisata baru di Ponorogo, baik wisata seni dan budaya maupun wisata alamPerkembangan pariwisata di Kabupaten Ponorogo terus melonjak bisa dilihat dari kunjungan wisatawan 2016 mencapai 249.294 orang. Rinciannya, wisatawan lokal sebanyak 249.229 orang dan wisatawan mancanegara sebanyak 65 orang.Kasi Promosi dan Informasi Dinas Kebudayaan Pariwisata Pemuda dan Olahraga Kabupaten Ponorogo, Farida Nur Aini, mengatakan angka tersebut mengacu pada wisatawan yang tercatat pemerintah dan mengunjungi sejumlah tempat wisata dan agenda budaya yang ada di Ponorogo. 


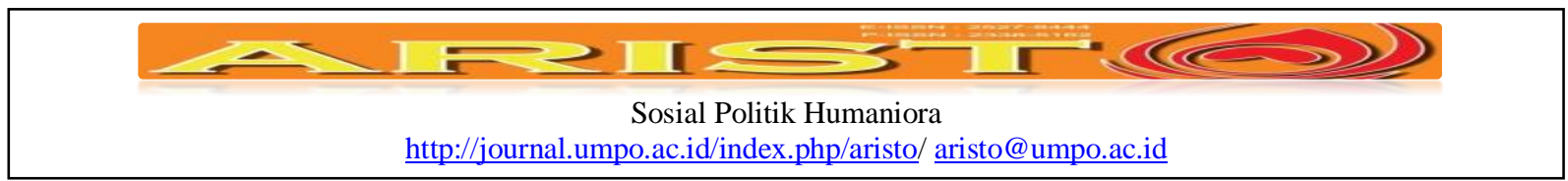

Dengan perayaan Grebeg Suro ini telah menjaga eksistensi masyarakat Ponorogo dalam menjaga budaya yang turun temurun dilakukan oleh generasi masa lalu.

Wilayah Ponorogo memiliki potensi alam budaya yang dapat dijadikan sebagai potensi pembangunan wilayah, dengan dijadikan sebagai destinasi pariwisata, obyek - wisata yang aada saat ini telah banyak di tunjang dnegan berbagi faislitas, seperti sarana transportasi, penginapan dan hotel, restoran, sehingga sangat potensial untuk dikembangkan kedepannya. 


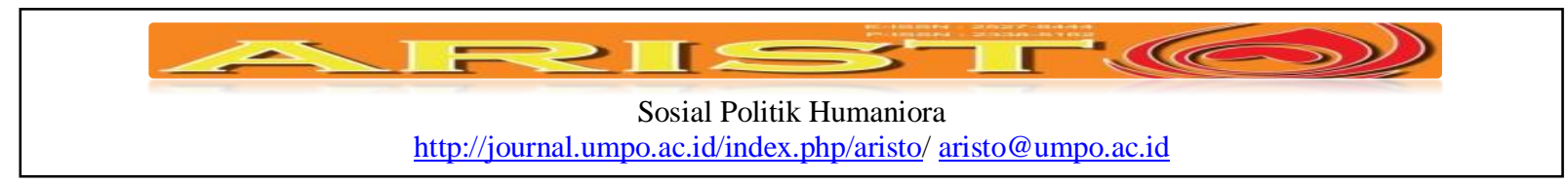

\section{Daftar Pustaka}

Andri Harianto, khoirurrosyidin. Upaya Dinas Kebudayaan dan Pariwisata Pemuda dan olahraga dalam melestarikan Kesenian Keling di Kabupaten Ponorogo, skripsi. 2017.

Agus Salim, Teori Dan Paradigma Penelitian Sosial (dar iDenzin Guba dan Penerapannya), Tiara Wacana, Yogjakarta, 2001

Badan Pusat Statistik Kabupaten Ponorogo, 2014, Ponorogo Dalam Angka.

C.A. Van Peursen, Strategi Kebudayaan. Penerbit Kanisius, Yogjakarta, 1988.

Departemen Pendidikan Nasional, 2012, Kamus Besar Bahasa Indonesia Pusat Bahasa, Jakarta: Gramedia Pustaka Utama.

Fatchan H.A, 2011, Metode Penelitian Kualitatif, Surabaya: Jenggala Pustaka Utama.

H. Kodyat, Sejarah Pariwisata dan Perkembangannya di Indonesia, PT Gramedia Pustaka Utama, Jakarta.

Koentjaraningrat, KEBUDAYAAN JAWA, Balai Pustaka, Jakarta, 1994.

Lexy J. Moleong, Metodologi Penelitian Kualitatif, PT Remaja Rosdakara, Bandung, 1995.

Lono Simatupang, Pergelaran Sebuah Mozaik Penelitian Seni-Budaya, Jala sutra, Yogjakarta, 2013.

Nyoman Kutha Ratna, 2010, Metodologi Penelitian Kajian Budaya dan Ilmu Sosial Humaniora Pada Umumnya, Yogyakarta: PustaPelajar

Nyoman S Pendit,1994, Potensi Pariwisata, Gramedia Pustaka Utama

Paul Stange, Politik Perhatian (Rasa Dalam Kebudayaan Jawa ), LKiS, Jakarta, 1998.

Peraturan Bupati Ponorogo Nomor 63 Tahun 2008, Tentang Uraian Tugas dan Fungsi Dinas Kebudayaan, Pariwisata, Pemuda dan Olahraga

Peraturan Daerah Kabupaten PonorogoNomor 1 Tahun 2012 tentang Rencana Tata Ruang Wilayah Kabupaten Ponorogo Tahun 2012-2032

Peraturan Daerah Kabupaten Ponorogo Nomor 10 Tahun 2008, tentang Struktur Organisasi Tata Kerja Dinas Daerah KabupatenPonorogo

Peraturan Pemerintah Nomor 38 Tahun 2007 tentang Pembagian Urusan Pemerintahan antara pemerintah, pemerintah daerah provinsi dan pemerintah kabupaten/kota 


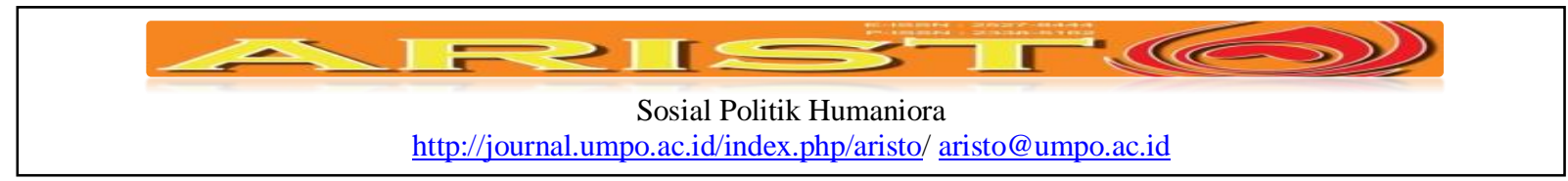

Profil Dinas Kebudayaan, Pariwisata, Pemuda dan Olahraga Kabupaten Ponorogo

Rencana Pembangunan Jangka Menengah Daerah Kabupaten Ponorogo, 2010 s.d 2015

Rencana Strategis Dinas Kebudayaan, Pariwisata, Pemuda dan Olahraga Kabupaten PonorogoTahun 2010-2015.

Robert Bogdan dan Steven J. Taylor, Kualitatif (Dasar - Dasar Penelitian), PT Usaha Nasional, Surabaya, 1993.

Totok Mardikanto, Komunikasi Pembangunan - Acuan Bagi Akademisi, Praktisi dan Peminat Komunikasi Pembangunan, Sebelas Maret Press, Surakarta, 2010.

Undang-Undang No.6Tahun 2014 tentang Pemerintahan Daerah

Undang-Undang Nomor 10 tahun 2009 tentang kepariwisataan

Undang-Undang Nomor 28 tahun 2009 tentang Pajak Daerah dan Retribusi Daerah

Undang-Undang Nomor 33 tahun 2004 tentang Perimbangan Keuangan Antara Pemerintah Pusat dan Pemerintah Daerah

Yoeti, 2001, Pengantar Ilmu Pariwisata

Yusuf Harsono dan Slamet Santoso, Dinamika Perubahan Struktur Sosial Para Warok Ponorogo (Studi Kasus: Mobilitas Sosial Vertikal - Horisontal Para Warok di Kabupaten Ponorogo), Fenomena JurnalI lmiah Ilmu Sosial - Humaniora, Vol 2. No 1, Januari 2005, ISSN 1693-8038. 